\title{
Problem and Prospects of Urban Agriculture in Some Wards of Chandernagore Municipal Corporation
}

\section{Tanushree Chakrabarti}

Department of Geography, The University of Burdwan, Burdwan-713104, West Bengal, India

*Corresponding author: mainak.bio@gmail.com (ORCID ID: 0000-0003-2719-6237)

Received: $13-04-2019$

Revised: $17-07-2019$

Accepted: 27-08-2019

\begin{abstract}
In twenty first century, urban agriculture has been gaining importance and potential in developing countries. The objective of the present study was to investigate the developments and problems of urban agriculture on the special emphasis on ward numbers 28,29 and 30 of Chandernagore Municipal Corporation (CMC) of Hooghly district of West Bengal. These three wards have been chosen due to the fact that all the said three wards were composed of areas that were rural before 1995, the years in which these wards were added to CMC to provide for expansion of the town. The significant part of population still dependent on agriculture. Particular crops, especially fruits and vegetables to ensure food security to the urban consumers.

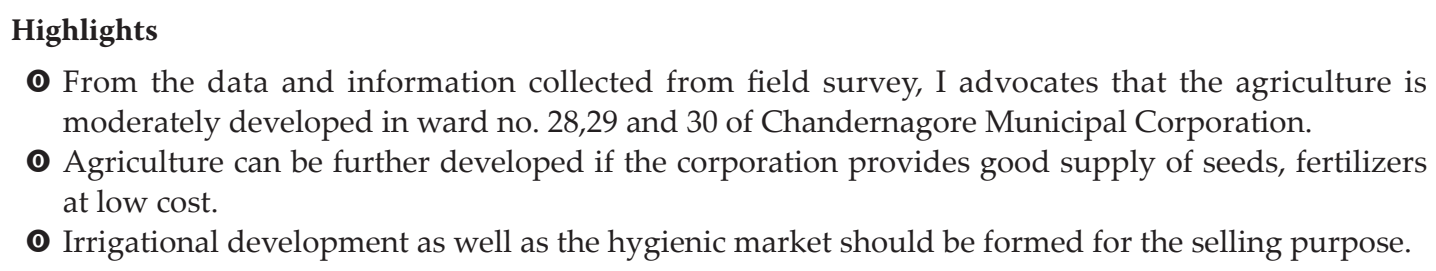

Keywords: urban agriculture, ward, rooftop gardening, bio-fertilizer, ground water

The growing population has created a number of questions over how to deal with sustainability in terms of transportation, housing needs, recreational interests and food supply. Urban agriculture is an industry that produces, processes and markets food and fuel, largely in response to the daily demand of consumers within a town, city or metropolis, applying intensive production methods, using and reusing natural resources and urban wastes, to yield a diversity of crops and livestock (Smit, 1996). The urban agriculture also has numerous benefits in terms of environmental sustainability aid environmental restoration and remediation through reusing abandoned areas, vacant plots improving water and air based natural resources, funna and flora and certain yard waste compost.

The present work is based on the special emphasis on ward number 28, 29 and 30 of Chandernagore municipal corporation. These three wards are chosen due to the fact that all the three wards are composed of areas that were rural before 1995, the year in which they were added to the corporation. The areas are still predominantly rural and the significant part of the population still dependent on agriculture to ensure food security to the urban consumers by increasing the availability of food.

To study the socio-economic condition of the agriculture and the non-agriculture households in ward numbers 28,29 and 30 of the said municipal corporation. To know about the problems and grievances of the urban farmers.

\section{DATA BASE AND METHODOLOGY}

Social research methods such as survey, questionnaire 
and interview have been used to assess the impact and contribution of urban agriculture or food security and nutrition.

Following methods have been adopted :
(A) Selection of survey areas
(B) Collection of primary data
(C) Collection of secondary data
(D) Collection of climatic data

\section{(A) Selection of survey areas}

In the present study ward number 28,29 and 30 under Chandernagore Municipal Corporation was selected as the study area because in those wards urban agriculture has been practiced. Moreover maximum number of farmers resides in the said wards.

\section{(B) Collection of primary data}

The major primary source of information based on the data collected from door to door survey in the three wards. I have surveyed 30 non-agricultural households and 30 agricultural households of the above mentioned wards i.e. total 90 agricultural and 90 non-agricultural households were surveyed.

The following questionnaire for non-agricultural household were prepared :

(a) Name of the head of the family

(b) Numbers of members

(c) Monthly gross income of the family

(d) Whether they possess a garden or practice rooftop gardening?

(e) Types of fertilizers (Chemical or Biofertilizer) they are using with their trade names and purpose of use

(f) What types of plants have been cultivated in their garden?

(g) Advantages and disadvantages of processing garden

Another separate questionnaire for the agricultural household was prepared with the following questions :

(a) Name of the head of the household.

(b) Number of the family members

(c) Monthly income of the family (d) Crops grown during winter, summer, monsoon and post monsoon

(e) Types of fertilizers used with their trade name and purpose

(e) Where do they sell agricultural products?

(f) From where do they get financial assistance?

(g) Source of irrigation

(h) Purpose of agriculture

(i) Future plans regarding the development of agriculture

After door to door survey the data obtained from the survey has been represented with suitable diagram:

\section{(C) Collection of secondary data}

The secondary data and information were collected from urban planners office in Chandernagore municipal corporation. The following data and information were collected :

(a) Land use map of 1684 and 2007 in Chandernagore municipal corporation and slope map of the added area.

(b) When and Why ward nos. 28,29 and 30 were included in Chandernagore municipal corporation?

(c) Condition of soil and ground water

(d) Percentage of agricultural land in specified wards of Chandernagore

(e) Socio-economic data of Chandernagore, like total households, sex - ratio, SC, ST population, main cultivators (including male and female), agricultural labour (total male and female), main workers (male and female).

\section{(D) Collection of climatic data}

The climatic data were collected from Climatic Sub-station, Chinsurah which consisted of rainfall, maximum and minimum temperature of the concerned regions and prepared and ergograph.

\section{OBSERVATION}

The main reasons for opting agriculture as occupation of households in ward no. 28,29 and 30 of Chandernagore municipal corporation are hereditary profession, farmers are not so educated 
to perform any other secondary or tertiary job, some farmers practice agriculture because they are not getting the job they desire to have.

Most of the farmers of the said wards use chemical fertilizers provide better and faster production than bio-fertilizer which are also not easily available. In addition, farmers grow crops for their commercial benefit and therefore they opt. chemical fertilizers for better and fast production.

\section{Irrigation}

The water from Saraswati river, pond and canal are the major sources of irrigation. However, river Saraswati do not flow through ward 28, therefore the farmers mainly depend on pond and canal (Mankundu canal and Agun khaki khal). In wards 29 and 30, Saraswati river is the main source of irrigation apart from pond. The cost for extraction of water from pond is ₹ 60 per hour.

\section{Mechanization of farm}

Most of the farmers use rented tractor to plough their agricultural plots. The rent of tractor is ₹ 350 per hour.

\section{Supply seeds and fertilizers}

The farmers of ward 28,29 and 30 procure seed from nursery of nearby markets because Chandernagore municipal corporation unlike the nearby gram panchyat does not provide seed and fertilizers at free of cost or at low cost.

\section{Financial assistance}

Saving of the farmers is the one and only financial assistance for them. Due to complex loan lending procedure, the farmers are reluctant to take loans from bank. They do not get any assistance from Chandernagore municipal corporation rather they have to pay several taxes (water tax, land tax and electric tax) to corporation.

\section{Sell of agricultural products}

Farmers of ward 29 and 30 sell their agricultural products to Baubazar market, whereas the farmer of ward no. 28 sell their products either in Jyoti market of sometimes in Baubazar market. During summer months the farmers do not get any profit after selling their agricultural products because the price of cultivating crops exceeds than the price which they get after selling crops. However, during monsoon season when the agriculture production is higher, they earned profit. During winter season the profit is moderate.

Urban agriculture in Chandernagore can also be classified in two types:

Type 1: Garden and rooftop gardening by the nonagricultural community

Type 2: Cultivation by the farmers

\section{Garden and rooftop gardening}

In ward no. 28,29 and 30 , out of 90 households 71 practice either gardening on rooftop or a combination of both rooftop and garden. It has been observed that some people grow medical plants like aloe vera, turmeric, curry leaves, tulsi and mint in rooftop gardening on plots. Most of the people grow flowers like rose, hibiscus, marigold in winter and jasmine in summer and fruits like mango, litchi, banana and vegetables like brinjal, pumpkin, gourd, cucumber in their garden. In ward 28 and 29 majority of households possess garden but in ward 30 most of the people practice garden and rooftop.

\section{Fertilizers use}

Most of the household use bio-fertilizers (vermicompost, green manure, organic manure, decomposed flowers and vegetables wastes as well as mustard oil cake). One household in ward 30 uses chemical fertilizers, three households in ward 30 and two households in ward 29 do not use any kind of fertilizer as they consider the soil of Chandernagore is fertile enough for gardening.

\section{Irrigation}

All the non-agriculture households use the water for irrigation provided by the corporation.

\section{Rainfall}

Chandernagore experiences typical monsoon climate. Highest amount of rainfall is experienced in the month of July $(279.6 \mathrm{~mm} \pm$ ) followed by 226 $\mathrm{mm} \pm$ in September, $188.6 \mathrm{~mm} \pm$ in August and $150 \mathrm{~mm} \pm$ in October. No rainfall in received in the month of January. 
The reasons for practicing gardening are :

(i) Gardening is the favorite hobby of many people.

(ii) Green plants provide oxygen and absorb carbon-di-oxide.

(iii) Mango tree provide shade during scorching summer afternoon.

(iv) People grow flowering plants for their worship

(v) Some people practice gardening for refreshing their mind as well as for time pass.

\section{Land Man ratio}

In 2011, the availability of land per man is high in ward no. 28(691) follow by ward no. 30(579) and ward no. 29 (499).

Table 1: Showing co-relation between land -man ratio main cultivators in each ward of Chandernagore Municipal Corporation

\begin{tabular}{ccc}
\hline Ward No. & Land man ratio & Main cultivators \\
\hline 1 & 111 & 1 \\
2 & 107 & 4 \\
3 & 116 & 1 \\
4 & 107 & 1 \\
5 & 70 & 0 \\
6 & 41 & 0 \\
7 & 77 & 8 \\
8 & 95 & 0 \\
9 & 80 & 3 \\
10 & 74 & 5 \\
11 & 25 & 1 \\
12 & 662 & 2 \\
13 & 98 & 1 \\
14 & 120 & 4 \\
15 & 142 & 1 \\
16 & 92 & 1 \\
17 & 78 & 0 \\
18 & 81 & 4 \\
19 & 89 & 4 \\
20 & 72 & 2 \\
21 & 117 & 1 \\
22 & 62 & 3 \\
23 & 75 & 2 \\
24 & 91 & 1 \\
25 & 53 & 1 \\
26 & 54 & 2 \\
27 & 48 & 411 \\
28 & 691 & \\
29 & 499 &
\end{tabular}

\begin{tabular}{lcc}
30 & 579 & 232 \\
31 & 125 & 0 \\
32 & 81 & 2 \\
33 & 23 & 5 \\
\hline
\end{tabular}

\section{DISCUSSION}

Urban agriculture is the practice of cultivating, processing and distributing food in or around of village, town and cities. It can also involve animal husbandry, aquaculture and horticulture (Awasthi, 2013). The rural-urban fringe characterized by small and medium sized farms oriented to the metropolitan markets that are more diverse than those in rural areas. The agriculture industry in this type of land adapts to the new demands of urban markets (Smit et al. 1996). According to Bailkey and Nasr (2000) typically urban agriculture applies intensive production methods, frequently using and reusing natural resources and urban wastes, to yield a diverse array of land, contributing to the food security, health and environment of the community. Beatly (2000) reported that the agriculture that happens to fall within or at the edge of a metropolitan area, perhaps adding its relationship to urban population. Lynch et al. (2002) suggests that in some ethics urban agriculture may already occupy 35 percent of the population and may supply upto 50 percent of urban fresh vegetables. Gupta and Gangopadhyay (2011) opined that urban agriculture and associated development can link between urban and rural areas.

Important advantage to the urban producer is the opportunity to use urban wastewaters. Better access and availability to good food for all, more vitamins and other essential micronutrients available per unit of food. Better access to protein at reduced cost to low income families. Ali and Srivastava (2017) emphasized that urban cities have major contribution to gross development product (GDP) growth of a country. With increasing urban sprawl the rural villages are getting converted into urban villages and gentrified in metropolitan cities like Delhi, depending of it on periurban areas for food production has increased.

In the present investigation in most of the times during summer season the farmers do not get any profit after selling agricultural products because the price of cultivating crops exceeds than the price which they get after selling crops. Seldom the 
farmers earned profit during monsoon when the production is higher than the other seasons. Profit in winter season is moderate. So, the development of urban agriculture in ward no. 28,29 and 30 is moderate. Farmers do not get adequate income for sustaining their life. Chandernagore Municipal Corporation do not provide any assistance to the farmers for development of agriculture. Irrigation facility is not much developed in ward no. 28 .

In all the said three wards, the non-agricultural households prefer to use bio-fertilizer as it is ecofriendly and do not cause soil pollution.

So my study areas I have found that out of 90 households surveyed, 71 families practice gardening rooftops. Most of the people grow flowers, fruits and vegetables in summer. In addition some people also grow medicinal plants on rooftop gardening on pots. According to Smit (1996) because of the density of the core area, urban agriculture usually takes place on rooftops and balconies, temporarily vacant plots, in converted buildings and sometimes in public parks.

\section{ACKNOWLEDGEMENMTS}

Grateful acknowledgements to the Head of the Department of Geography, The University of
Burdwan, Burdwan 713104, West Bengal for this generous help during the present investigation.

\section{CONCLUSION}

The urban agriculture practice may be developed in Chandernagore if the farmers get assistance from Chandernagore municipal corporation by supplying seeds, fertilizers at low cost. The municipal corporation should establish a farm school where the farmers could get training and information regarding improved modernized agriculture. The corporation should take initiative regarding irrigational development by constructing ponds, deep wells etc. Twiss et al. (2003) noticed that community garden also provide great access to fresh and nutritious vegetables and have a significant role in addressing public health.

\section{Future plans of urban agriculture}

1. The agricultural labors should plan to purchase their own land in future.

2. To improve carrot cultivation in winter and hybrid ladies fingers cultivation in monsoon.

3. Use of modern scientific technology in order to increase the agricultural production.

Figs. 1 to 15. Showing photographs of map, study areas, man-land ratio and non-cultivars ratio of ward no. 28,29 and 30 in Chandernagore Municipal Corporation

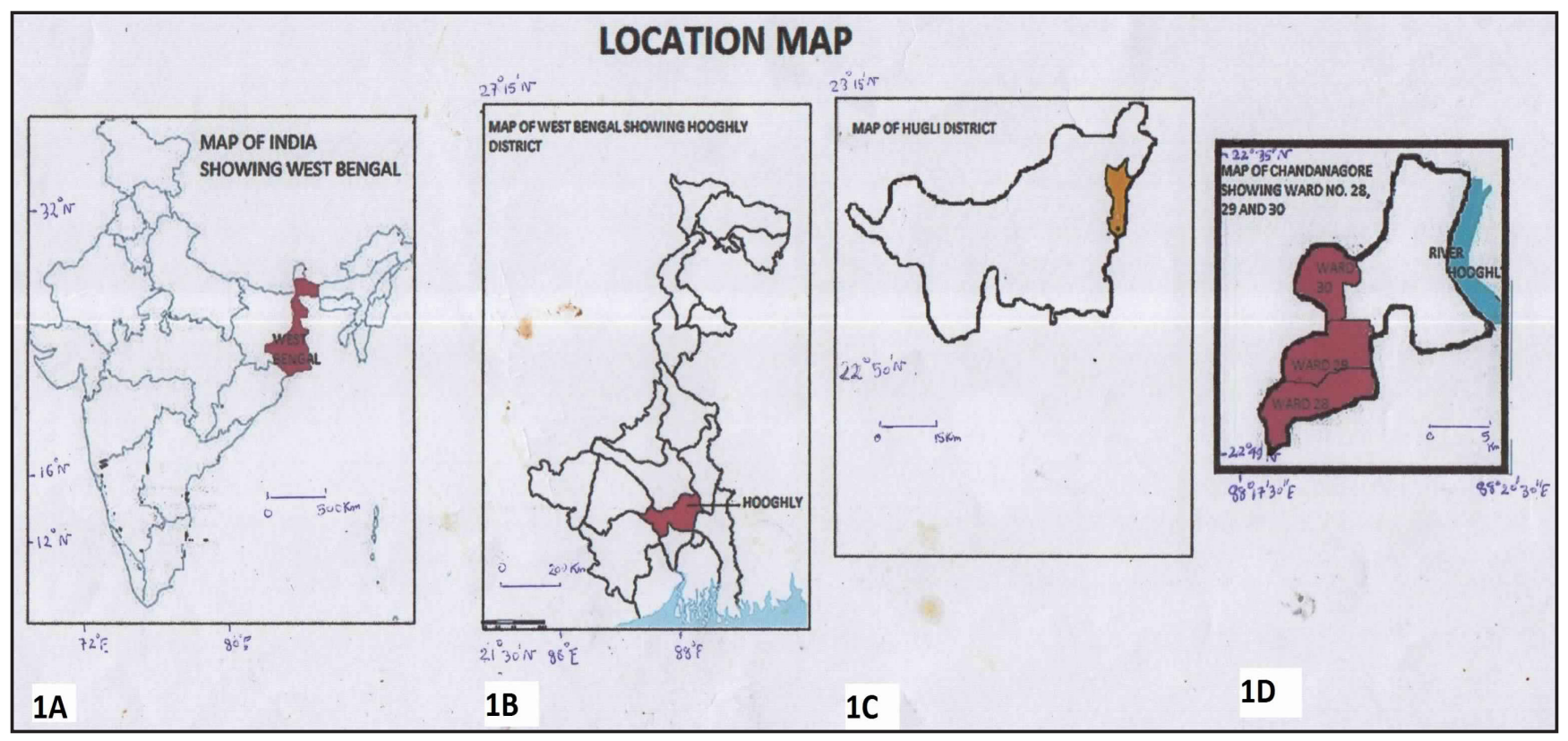

Fig. 1 (A): Showing location map of India and West Bengal; (B) Showing location map of Hooghly district of West Bengal; (C) Showing location map of Hooghly district; (D) Showing location map of Ward no. 28,29 and 30 of Chandernagore Municipal Coporation 


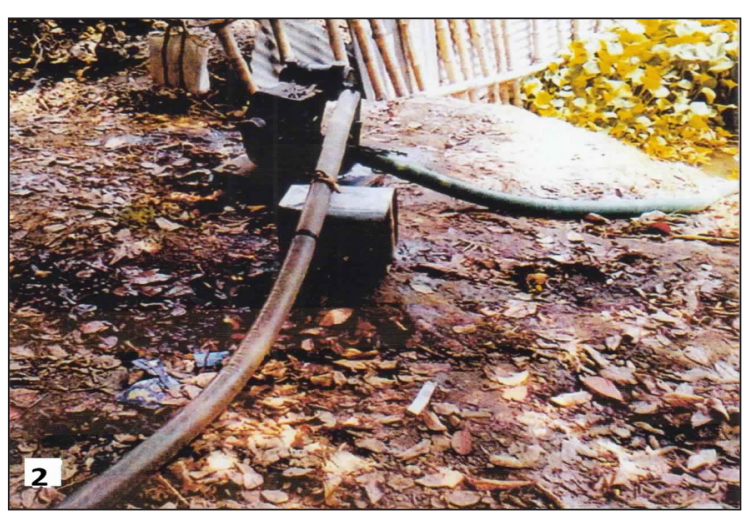

Fig. 2: Showing irrigation system of ward no. 28

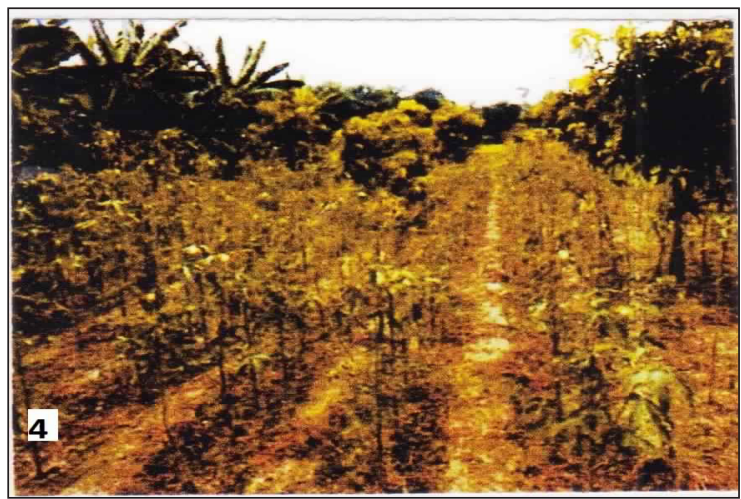

Fig. 4: Crop cultivated by farmers in ward no. 28

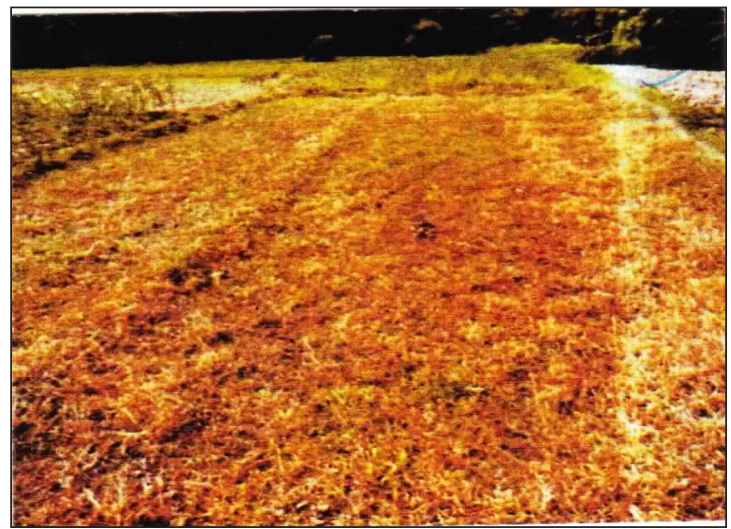

Fig. 6: Crop cultivation in Ward no. 29

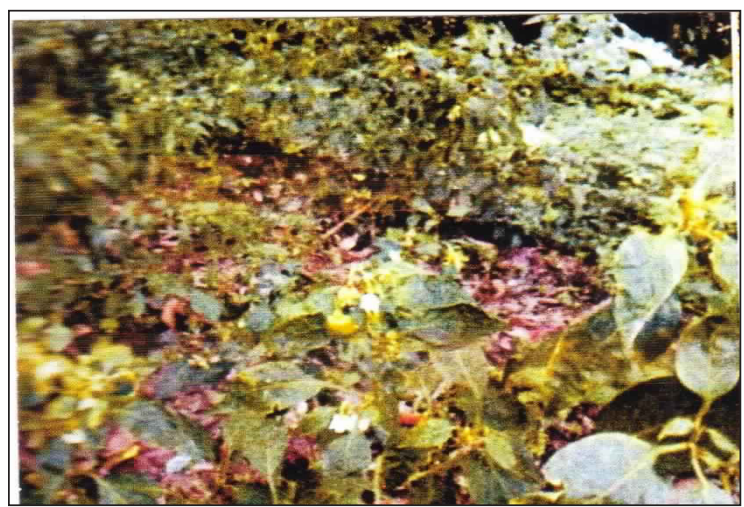

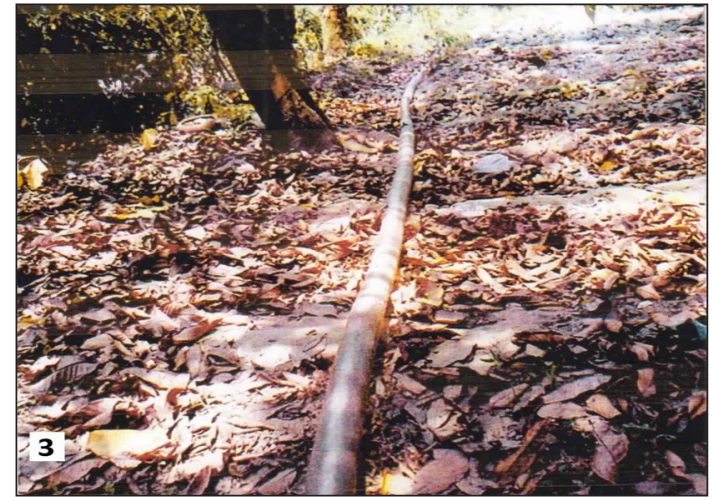

Fig. 3: Showing irrigation system in other places of ward no. 28

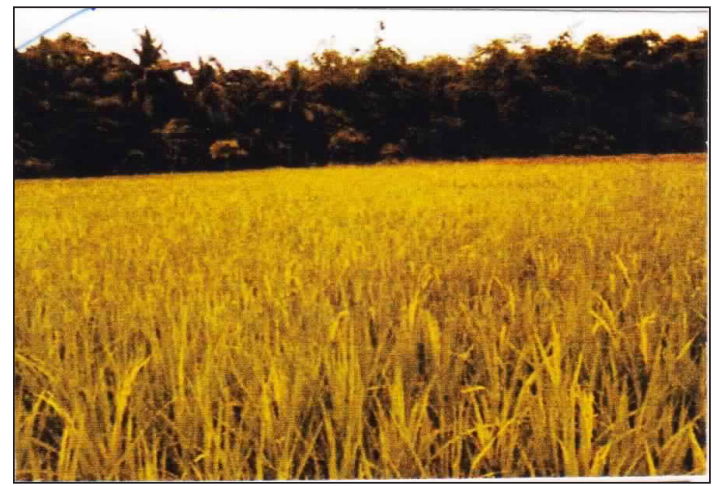

Fig. 5: Paddy cultivation in ward no. 28

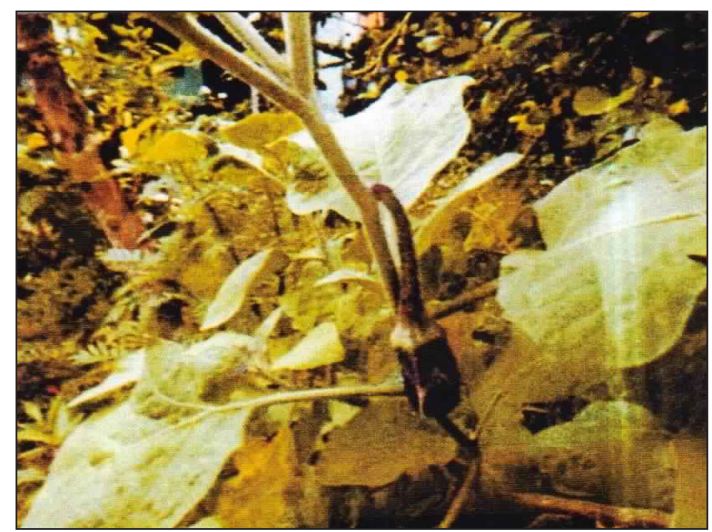

Fig. 7: Vegetable cultivation in ward no. 30

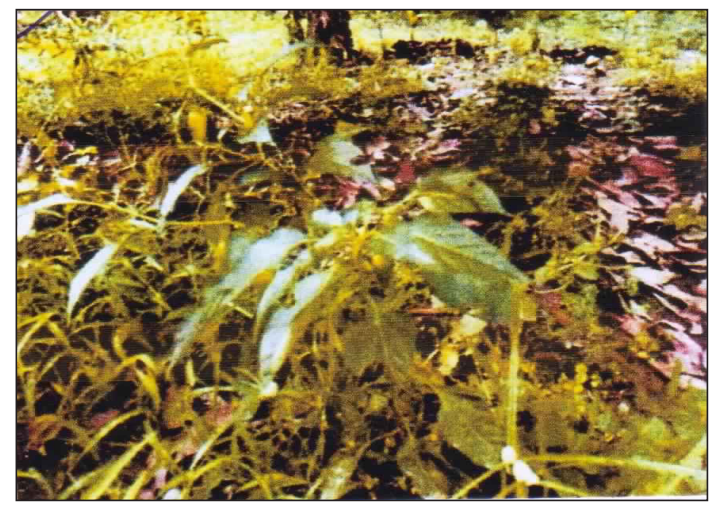

Fig. 8: Roof top gardening in non-agricultural household of ward Fig. 9: Gardening in non-agricultural household of ward no. 28 no. 28 


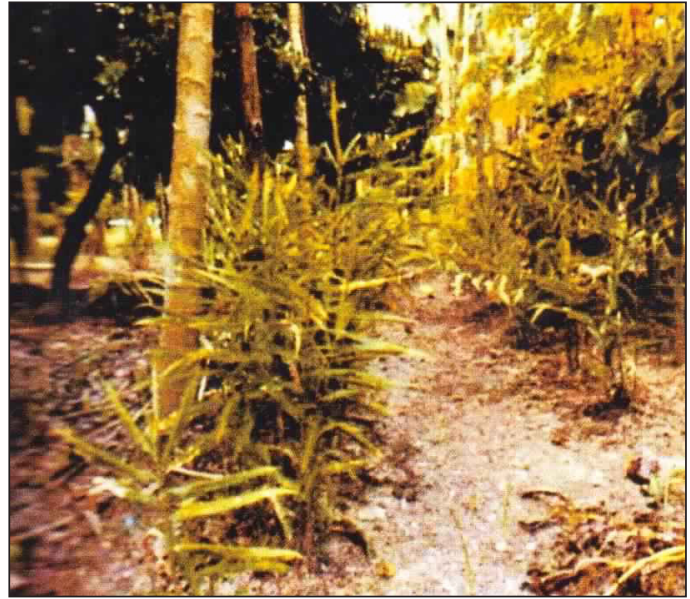

Fig. 11: Gardening in non-agricultural household of ward no. 30 Fig. 12: Showing correlation of Man-land ratio of each ward in Chandernagore Municipal Coporation

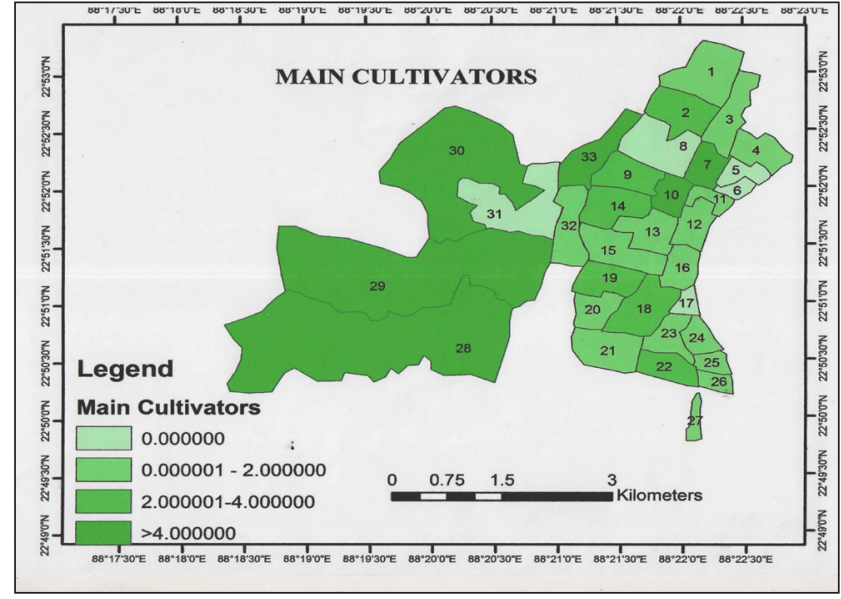

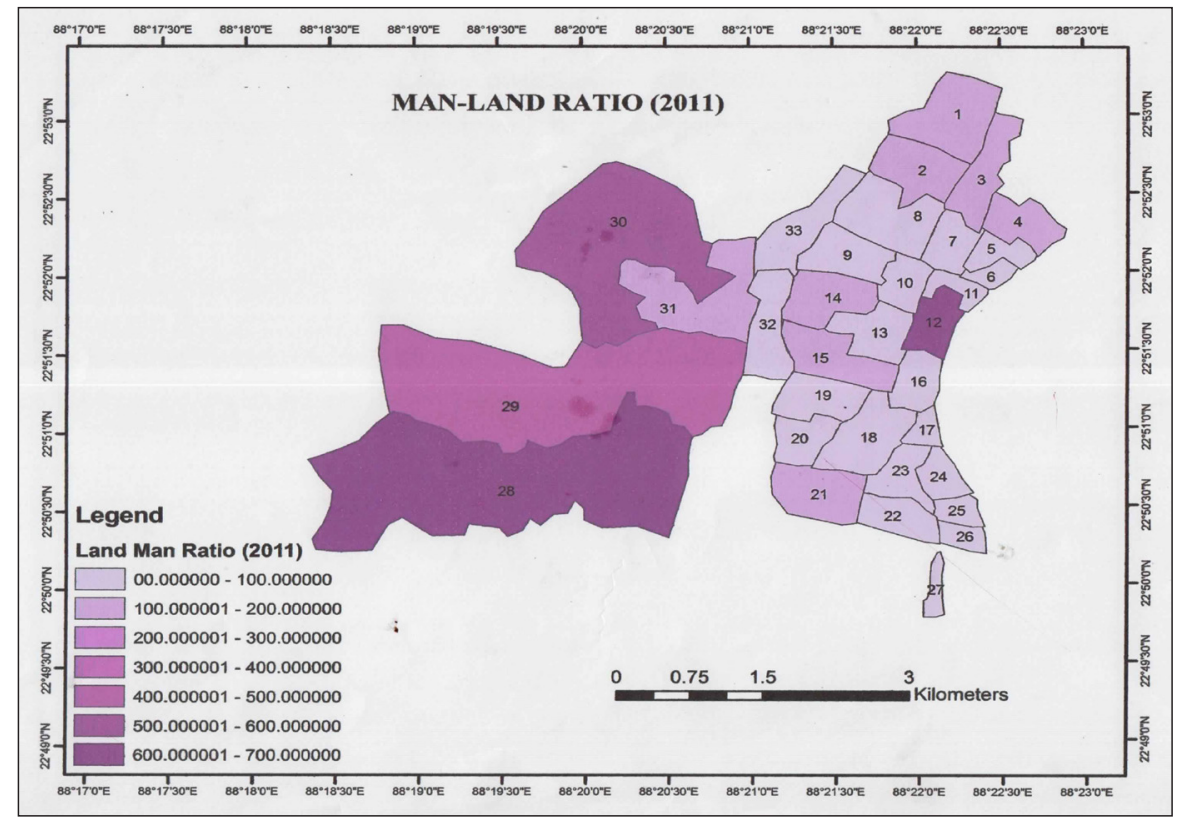

Fig. 13: Showing correlation man-cultiva tors ration of each ward in Chandernagore Municipal Coporation

\section{REFERENCES}

Ali, F. and Srivastava, C. 2017. Futuristic urbanism - An overview of vertical farming and urban agriculture for future cities in India. Int. J. Adv. Res., Sci., Eng., Tech., 4(4): 3767-3775.

Awasthi, P. 2013. Urban agriculture in India and its challenges. Int. J. Environ. SCI., Development and Monitoring, 4(2): 48-51:2013.

Bailkey, M. and Nasr, J. 2000. From brownfields to greenfields: Producing food in North American cities. Community Food Security News.

Beatley, T. Grreen Urbanism. 2000. Learning from European cities. Washington DC. Island press.

Gupta Gangopadhyay, S. 2011. Good practice urban agriculture and better unit environment in India. Inst. Town Planners, Ind. J., 8: 21-26. 
